\title{
Operations research in reproductive health and family planning at the Cairo Demographic Center
}

Magdi A. Ibrahim

James R. Foreit

Population Council

M.E. Khan

Population Council

Follow this and additional works at: https://knowledgecommons.popcouncil.org/departments_sbsr-rh

Part of the Demography, Population, and Ecology Commons, Health Services Research Commons, and the International Public Health Commons

How does access to this work benefit you? Let us know!

\section{Recommended Citation}

Ibrahim, Magdi A., James R. Foreit, and M.E. Khan. 2001. "Operations research in reproductive health and family planning at the Cairo Demographic Center," FRONTIERS Final Report. Washington, DC: Population Council. 


\title{
Operations Research in Reproductive Health and Family Planning \\ at Cairo Demographic Center
}

\author{
Dr. Magdi Ibrahim \\ Cairo Demographic Center \\ Dr. James Foreit \\ Dr. M.E. Khan \\ Population Council
}

March 2001

Operations Research in Reproductive Health and Family Planning at Cairo Demographic Center, June 1, 1999 - January 31, 2001. This study was funded by the U.S. AGENCY FOR INTERNATIONAL DEVELOPMENT (USAID) under the terms of Cooperative Agreement Number HRN-A-00-98-00012-00 and Subagreement number A199.42A. The opinions expressed herein are those of the authors and do not necessarily reflect the view of USAID. 


\section{SUMMARY}

The goals of the two year training program at the Cairo Demographic Center (CDC) were to increase the number of researchers using operations research (OR), and to help institutionalize the ability of the Center to offer training in operations research in reproductive health. This report (1) evaluates the effectiveness of the program in accomplishing its goals and (2) provides feedback for OR curriculum development.

The project trained researchers with program and policy-making responsibilities. It provided participants with the experience of designing an operations research project and built participants' skills in communicating research results to managers. A total of 41 participants from 16 different countries attended the 1999 and 2000 courses.

Participant evaluations showed that, overall, the course met its objectives. The first year's program received high marks from participants, and these increased somewhat in the second year. Participant evaluations were used to modify the training.

After the completion of the second year course, CDC incorporated operations research training in its regular diploma curricula. The Center plans to offer short term training programs for UNFPA-and WHO-sponsored students from the Middle East and subSaharan Africa. Basic funding for the OR curriculum has been assumed by CDC. The first course without FRONTIERS financial input was taught in 2001.

The impact of the OR training on 1999 course graduates was assessed through questionnaires administered immediately after the training and one year after the training. The training that the students received in OR has mainly been incorporated into their own teaching activities, but a substantial number of students have also designed and worked on OR projects, and submitted OR proposals to donors for funding. A major problem in increasing course graduate involvement in OR is that many do not work in institutions or settings (Census Bureaus, Police Crime Statistics Units) that are conducive to operations research activities. 


\section{CONTENTS}

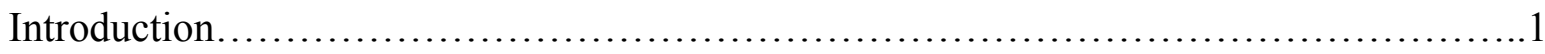

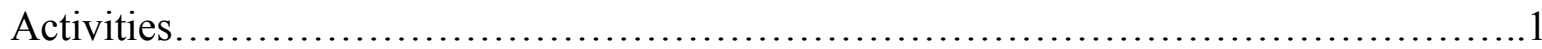

Participants........................................................

Course Description and Implementation.................................2

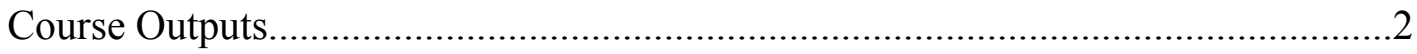

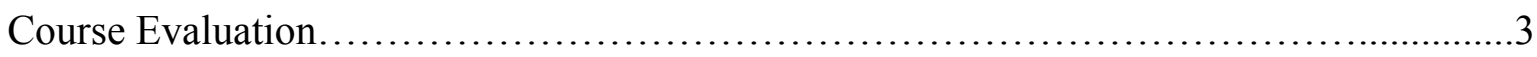

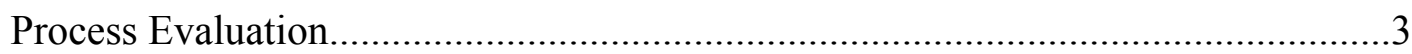

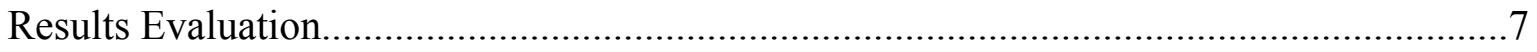

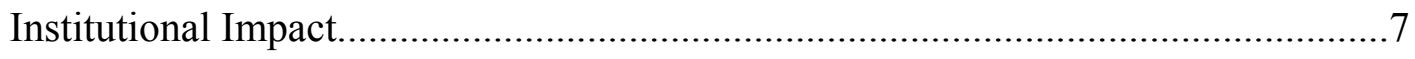

Impact on Individual Participants................................................................

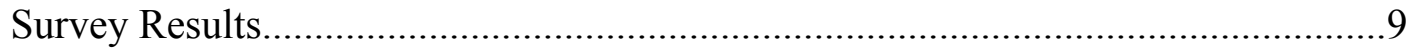

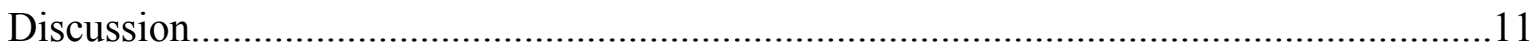

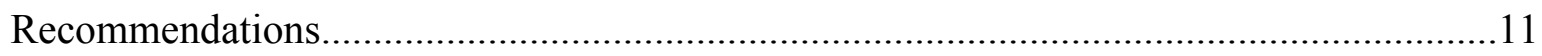

Appendices............................................................. 12 


\section{Introduction}

The Cairo Demographic Center (CDC) was established in 1963 with joint sponsorship by the Government of Egypt and the United Nations. The Center continues to receive UNFPA and Government of Egypt support. CDC has also received grants and contracts from USAID, IDRC, the Population Council, FHI and the Population Information Program of Johns Hopkins University. CDC is a member of the Committee for International Cooperation in National Research in Demography (CICRED). As a recognized interregional training center in population and related fields, CDC pursues a full-time program of training, research and technical assistance. The Center offers diplomas in Demography, Population and Development at the bachelor's, master's and doctoral levels. CDC also offered ten-month certificate courses as part of the Global Programme of Training in Population and Sustainable Development sponsored by UNFPA during the period 1993-2000.

\section{Operations Research Program Setting}

CDC collaborated with FRONTIERS from June 1999 to January 2001 to teach two certificate granting operations research (OR) courses in Cairo for mid-level researchers associated with national population commissions, reproductive health programs, universities, and research institutes. The two courses were implemented for one month each during JulyAugust 1999 and 2000.

\section{Objectives}

The ultimate goals of the collaboration are (1) to increase the number of researchers using OR, and (2) to institutionalize the ability of the Cairo Demographic Center to offer training in operations research in reproductive health. The specific objectives of the 1999 and 2000 courses included:

1) To train researchers with program and policy-making responsibilities in operations research.

2) To provide participants with the experience of designing an operations research project.

3) To build participants' skills in communicating research results to managers.

\section{ACTIVITIES}

\subsection{Participants}

As planned, 41 participants, including 21 men and 20 women, attended the two courses. Most participants were mid-level researchers or program managers. They worked in Census and other government statistical bureaus, for national population councils, reproductive health programs, ministries of health and universities. The 1999 course was attended by 20 students from 12 countries. Twelve students were drawn from UNFPA sponsored Global Programme participants, 2 from CDC, 3 from FRONTIERS OR Projects in Egypt, and 3 from FRONTIERS OR projects in other Asian countries. The students came from Armenia, 
Bangladesh, Egypt, The Gambia, Indonesia, Kenya, Liberia, Nigeria, Palestine, Romania, South Africa and Zambia.

The 2000 course was attended by 21 students from 12 countries; 12 students were Global Programme participants, 3 from CDC, 2 from FRONTIERS OR Projects in Egypt, and 4 from OR projects in other Asian and African countries. Students came from Bangladesh, The Gambia, Nigeria, Egypt, Palestine, Liberia, Ghana, Yemen, China, Philippines, Sudan, and Uganda. CDC handled all administrative arrangements including visas, housing, per-diem and registration. The list of participants who attended the courses is provided in Appendix I.

\subsection{Course Description and Implementation}

The course consisted of classroom activities, field visits, groups activities and regular readings followed by discussions and critique. Major topics covered in classroom activities included: the definition of reproductive health and operations research, program components, research topic identification, experimental design, qualitative methods, economic evaluation of health programs, situation analysis and presentation skills. The course was taught by CDC, FRONTIERS staff and consultants (course outlines are shown in Appendix II).

The 1999 course took place at CDC during the period from $18^{\text {th }}$ July to $17^{\text {th }}$ August 1999 . The course lasted 24 working days, and consisted of 120 hours of instruction, classroom lectures, working groups and other activities including readings and seminars. The 2000 course took place at CDC during the period from $24^{\text {th }}$ July to $24^{\text {th }}$ August 2000. The course lasted 23 working days, and consisted of 124 hours of instruction.

\subsection{Course Outputs}

Operations research proposals were the major course outputs. Participants were formed into four groups of five participants to produce operations research proposals. By the end of each course, each group submitted a Reproductive Health OR Proposal. These proposals were presented by the groups in a seminar organized on the last day of the course. These proposals include:

\section{$\underline{1999}$}

1) The Effect of Retraining Health Care Providers on the Utilization of RTIs/HIV/AIDS Services in Kenya.

2) Improving Clinical Services Improvement Project (CSI) Service Utilization by Providing Free Transportation.

3) Increasing the Utilization of Service Facilitates through Training the Service Providers on Quality of Care.

4) Counseling Performance and Contraceptive Use: Effect of a Training Programme for Health Providers. 
1) An Experimental Operations Research Study to Increase Modern Contraceptive Use through Counseling of Postpartum Mothers in a Hospital Setting.

2) The Impact of Interpersonal Communication Skills (ICS) Training Program of Family Planning Service Providers in Effective Information Campaign on FP Services and Contraceptive Use In Liberia.

3) Effect of Improved System of Pill Administration in Rural Upper Egypt.

4) The Impact of IEC Program on Increasing Awareness of Family Planning Methods and Use in Rural Areas in Western Uganda.

\section{COURSE EVALUATION}

FRONTIERS capacity building activities are evaluated on both process and outcomes. Process evaluation is used to modify the teaching program. Capacity building outcome evaluation is used to determine if the course actually resulted in the adoption of OR training into the CDC curriculum, and in operations research activities by individuals attending the courses.

\subsection{Process Evaluation}

Participants were asked to evaluate the course on the final day of classes. The purpose of the evaluation was to obtain feedback that could be used in improving subsequent courses. Students were asked if course modules provided clear introductions to the topics covered, and were asked to rate the usefulness of course components in their future work. The evaluation instrument also solicited comments from individuals on the course. The process evaluation for both courses are compared in the sections below. Tables 1 and 2 compare the degree to which each course met its didactic objectives, as rated by the students who were asked to give "yes" or "no" responses to questions about each objective. When a "no" response was given, the respondent was asked to explain why he/she did not feel the objective was met. These open ended responses were used to improve the following course. 


\begin{tabular}{|c|c|}
\hline \multicolumn{2}{|c|}{$\begin{array}{c}\text { Table 1: Participants' evaluation of course achievements of six basic } \\
\text { objectives: Cairo, } 1999\end{array}$} \\
\hline \multicolumn{2}{|c|}{ Q: Do you think that the course fulfilled the following objectives? } \\
\hline . Gave a clear definition of $\mathrm{OR}$ & $\mathrm{Yes}=19 \quad \mathrm{No}=1$ \\
\hline & \\
\hline \multicolumn{2}{|c|}{$\begin{array}{l}\text { Comments from those responding "no" to question 2: "The focus of the training } \\
\text { was mainly on family planning and the other components of reproductive health } \\
\text { were less covered." "Training would be better if it includes more information abou } \\
\text { reproductive health." "Needs to be more specific and clear." "Contents were no } \\
\text { adequate." "No lecture about structure and concern of reproductive health programs."' } \\
\text { "There is a need for more explanation on reproductive health and its components, as } \\
\text { well as its importance and implications especially with regard to the non-globa } \\
\text { participants." "You need to emphasize reproductive health issues, not just family } \\
\text { planning." }\end{array}$} \\
\hline & Yes $=20 \mathrm{~N}$ \\
\hline 4. Gav & $\mathbf{I}$ \\
\hline \multicolumn{2}{|c|}{$\begin{array}{l}\text { Comments from those responding "no" to question 4: "The qualitative research } \\
\text { introduction by different specialists with different points of view made it somewhat } \\
\text { confusing. Did not take enough time, and the responsible professor left and the } \\
\text { person in charge instead tried to find a solution and an alternate professor." "Lessons } \\
\text { on qualitative research were overcrowded and discussed in a hurry without giving us } \\
\text { a chance to understand." "The qualitative study sessions need more explanation and } \\
\text { more exercises and the time is very short." }\end{array}$} \\
\hline 5. Gave clear introduction to economic evaluation & Yes $=15 \quad \mathrm{No}=5$ \\
\hline \multicolumn{2}{|c|}{$\begin{array}{l}\text { Comments from those responding "no" to question 5: "In the economic evaluation } \\
\text { most of us do not have any background about economics and this was teaching in a } \\
\text { very high level and we need a very simple way to reach the idea of economic } \\
\text { evaluation of the health programs." "It was a very bad session and not clear. Maybe } \\
\text { next time you should choose another program." "The professor started from a very } \\
\text { high level despite that the group told him that we have no idea. The exercises he gave } \\
\text { were not clear; he informed us that it contains tricks." "More time was needed. } \\
\text { Minimum seven days, and should not have taken for granted that all the participants } \\
\text { have a background in economics or finance." "It needs practical applications such as } \\
\text { field visits to some programs for organizations working the field of OR." }\end{array}$} \\
\hline . Gave a clear introduction to situation analysis & \\
\hline
\end{tabular}

Some students felt that more time needed to be spent on non-family planning areas of reproductive health. The sessions on qualitative research were cited as being poorly organized, and the content of the economic evaluation sessions was too advanced given the background of participants. As shown in Table 2 below, in the 2000 course, many fewer "no" answers were received. In part, this was due to efforts to respond to 1999 criticisms. A new instructor was brought in to teach the reproductive health module. The module on qualitative research was put in charge of a single instructor who was present for the entire course section. The number of topics in economic evaluation was reduced, and more time 
was spent on teaching the mechanics of cost analysis and cost-effectiveness analysis. As shown in Table 2, the changes helped solve the problems identified in qualitative methods. However, despite the fact that economic evaluation was substantially simplified, students still had problems with the module.

\section{Table 2: Participants' evaluation of course achievements of six basic objectives: Cairo, 2000}

Q: Do you think that the course fulfilled the following objectives?

1. Gave a clear definition of OR in Reproductive $\mathrm{Yes}=21 \mathrm{No}=0$ Health

2. Gave a clear introduction to the structure and $\mathrm{Yes}=21 \mathrm{No}=0$ concerns of reproductive health programs

3. Gave a clear introduction to intervention research $\quad \mathrm{Yes}=21 \quad \mathrm{No}=0$

4. Gave a clear introduction to qualitative research $\quad \mathrm{Yes}^{2}=21 \quad \mathrm{No}=0$

5. Gave clear introduction to economic evaluation $\quad \mathrm{Yes}=14 \quad \mathrm{No}=7$

Comments from those responding "no" to question 5: "In the economic evaluation most of us do not have any background about economics and this was teaching in a very high level and we need a very simple way to reach the idea of economic evaluation of the health programs."

6. Gave a clear introduction to situation analysis $\quad$ Yes $=19 \quad \mathrm{No}=2$

Participants were asked what they enjoyed most and least about the course. The open-ended responses were re-coded into closed-ended categories. These are shown in Table 3 below for both 1999 and 2000 (each respondent could list more than one item).

\begin{tabular}{|l|l|l|l|l|}
\hline \multicolumn{3}{|c|}{ Table 3: Course topics enjoyed most and least: Cairo, 1999-2000 } \\
\hline TOPIC/RESPONSE & \multicolumn{2}{|c|}{ ENJOYED MOST } & \multicolumn{2}{c|}{ ENJOYED LEAST } \\
\hline & 1999 COURSE & 2000 COURSE & \multicolumn{1}{|c|}{ 1999 COURSE } & 2000 COURSE \\
\hline Making Presentations & 5 & 8 & 0 & 4 \\
\hline Intervention Research & 7 & 5 & 0 & 0 \\
\hline Everything & 5 & 3 & 0 & 0 \\
\hline Instructors & 6 & 0 & 0 & 0 \\
\hline Qualitative Research & 3 & 4 & 2 & 0 \\
\hline Working Groups & 2 & 3 & 0 & 1 \\
\hline Situation Analysis & 2 & 3 & 0 & 1 \\
\hline Writing Proposal & 1 & 1 & 0 & 0 \\
\hline Reproductive Health & 1 & 2 & 0 & 0 \\
\hline Readings & 1 & 0 & 0 & 2 \\
\hline Economic Analysis & 2 & 1 & 5 & 6 \\
\hline Computer Facility & 1 & 0 & 3 & 1 \\
\hline Social Activities & 0 & 0 & 2 & 0 \\
\hline Facilities & 0 & 0 & 1 & 0 \\
\hline Nothing was very bad & 0 & 0 & 0 & 7 \\
\hline
\end{tabular}

The course received high marks for the quality of the teaching staff and course organization. The modules on intervention research and situation analysis seem the most enjoyable. Students also enjoyed the opportunity to present the OR proposals they had written. 
Participants would have liked more time for the course, better facilities, and more recreation and social opportunities. The module on economic evaluation was again mentioned as needing work.

In an additional attempt to judge participant satisfaction with the course, we asked those students who had previously taken courses at CDC to compare the OR course to others they had received at the institution. The OR course compared quite favorably, as can be seen in Table 4.

\begin{tabular}{|l|l|l|}
\hline \multicolumn{3}{|c|}{ Table 4: Participants comparison of OR course to other courses taken at CDC: } \\
Cairo, 1999-2000 \\
\hline \multicolumn{2}{|c|}{ Compared to other course you have had at CDC would you say this course is: } \\
\hline COMPARATIVE RATING & \multicolumn{1}{|c|}{ 1999 COURSE } & \multicolumn{2}{c|}{ 2000 COURSE } \\
\hline Below Average & 0 & 1 \\
\hline Average & 3 & 14 \\
\hline Above Average & 10 & 15 \\
\hline Total Respondents & 13 & 0 \\
\hline
\end{tabular}

Both the 1999 and 2000 courses were rated above average by the participants. Consistent with the shift toward greater satisfaction noted between the courses in Tables 1 and 2 above, the 2000 course was rated somewhat higher than the 1999 course. This may be a function of the course changes made between the two years.

Finally, participants were asked to rate the potential relevance of course components to their jobs. Respondents were asked the question, "How useful do you think the following course components will be in your work?" They were asked to scale their responses from "not very useful" to "very useful". Responses are shown in Table 5 below.

\begin{tabular}{|l|c|c|c|c|c|c|c|c|}
\hline \multicolumn{7}{|c|}{ Table 5: Potential usefulness of OR course components to participant } \\
job activities: Cairo, 1999-2000 \\
\hline \begin{tabular}{c}
\hline COURSE \\
COMPONENT
\end{tabular} & $\mathbf{1 9 9 9}$ & $\mathbf{2 0 0 0}$ & $\mathbf{1 9 9 9}$ & $\mathbf{2 0 0 0}$ & $\mathbf{1 9 9 9}$ & $\mathbf{2 0 0 0}$ & $\mathbf{1 9 9 9}$ & $\mathbf{2 0 0 0}$ \\
\hline Intervention Research & & 2 & & & 3 & 2 & 17 & 17 \\
\hline Qualitative Research & & & 2 & & 3 & 4 & 15 & 17 \\
\hline Economic Evaluation & & 2 & 2 & 1 & 10 & 4 & 7 & 14 \\
\hline Situation Analysis & & 1 & & 1 & 5 & 2 & 15 & 17 \\
\hline Making Presentations & & & & & 1 & 1 & 19 & 20 \\
\hline Writing Proposals & & & & & 2 & & 18 & 21 \\
\hline
\end{tabular}

The modal response for five of the six components was "very useful" in 1999. The sixth component, economic evaluation, received a modal response of "somewhat useful." In 2000 the modal response for all components was "very useful." In both years, the course exercises designed to provide participants with practice in making presentations and writing research proposals were rated at the top of job related usefulness. 


\section{RESULTS EVALUATION}

The subaward was to produce two results: 1) enable CDC to incorporate OR instruction into their regular curriculum; and 2) increase OR activities among course graduates after returning to their jobs.

\subsection{Institutional Impact}

In 2001, the Cairo Demographic Center added operations research to its undergraduate course curriculum. CDC offers two undergraduate degrees. The General Diploma provides basic training in a wide variety of statistical and demographic techniques. It is designed to produce entry level professionals for census bureaus and statistical institutes. Enrollment in the General Diploma is usually 45 - 50 students, with approximately one third from countries outside Egypt. A total of 25 hours of instruction in OR, emphasizing experimental design and qualitative evaluation, was provided to General Diploma students in June 2001.

The Special Diploma provides more advanced training in demographic techniques, and exposes students to substantive issues such as population and sustainable development, reproductive health and gender issues. This program usually has $15-20$ students, with approximately one fourth from countries outside Egypt. A total of 15 hours of instruction in OR was added to the Special Diploma curriculum. Both programs are supported by the Government of Egypt and UNFPA (foreign student support) funds. Three CDC faculty who were active in the FRONTIERS-sponsored courses are responsible for the OR curriculum. Under an informal agreement, FRONTIERS continues to assist CDC efforts to become a major OR center. Staff from FRONTIERS offices in Egypt and elsewhere lecture at CDC on operations research topics, and the Center receives OR related teaching materials from FRONTIERS. The continuing relationship is mutually beneficial. It allows CDC to expose its students to experienced OR staff, while the teaching activities allow FRONTIERS to disseminate its perspective on program relevant research more widely. Finally, in an attempt to continue strengthening the actual operations research experience of CDC faculty, the Center is invited to participate in FRONTIERS OR projects whenever appropriate. CDC also included lectures on OR in a one month course on quality of care in reproductive health that they co-sponsored with PPD (South to South Collaboration), a program of the Rockefeller Foundation.

$\mathrm{CDC}$ also promotes its expertise in operations research internationally. It plans to continue offering short courses in the topic, and has begun to negotiate with WHO to provide training for students from Africa and the Middle East. These negotiations began in the last quarter of 2000 when CDC was invited to a regional WHO meeting in Beruit. Negotiations will continue when CDC attends a capacity building consultancy in Geneva in September 2001.

Process of institutionalization $\mathrm{CDC}$ was selected for institutionalization activities because it was known to FRONTIERS staff who had used CDC expertise on OR projects. CDC was interested in modernizing its curriculum, and its experiences with OR made it receptive to adding the subject to its curriculum. CDC was also attractive to FRONTIERS because it was funded by the Government of Egypt and several international donors, and was not dependent 
on FRONTIERS financing. $\mathrm{CDC}$ also has an international reputation and draws large numbers of students from the Middle East, Africa and Asia.

In working with CDC, FRONTIERS used the following institutionalization strategies:

- CDC faculty members were made responsible for course implementation and were involved in teaching duties. This aided CDC understanding of OR content and methodology, and gave them "hands-on" experience running an OR course.

- CDC faculty and other local resource persons were given increasing responsibility for conducting the training sessions. FRONTIERS staff presence was reduced greatly between the first and second training courses.

- Copies of all transparencies, PowerPoint presentations, handouts, lecture notes and sample data sets used in practice analyses were provided to CDC for future use.

- Copies of all assigned and recommended reading materials were donated to the agency library. A large supply of basic OR texts was also donated for use in subsequent courses.

- Conversations with the CDC Director concerning introduction of OR into the Center curriculum were initiated early in the collaboration and were continued throughout the two year process. During courses, FRONTIERS staff briefed the Director on course activities on an almost daily basis.

- An informal, long term comittment to support OR at CDC was made to the Director by FRONTIERS.

- FRONTIERS staff participated in curriculum develpment meetings with CDC staff in designing the OR contents to be included in Diploma Courses. FRONTIERS staff will also be invited as guest lecturers at CDC OR courses.

- To raise the OR profile of CDC, FRONTIERS helped promote CDC attendence at meetings held by WHO.

\subsection{Impact on Individual Participants}

A second results indicator is the extent to which course participants use their training after they return to their jobs. In this section we examine two aspects of utilization of training: 1) the number and type of operations research activities carried out by the participants in the year following the CDC course; and 2) specific skills learned in the course that were used by participants. Since our ultimate objective is to increase the use of OR in service delivery agencies we also examine the extent to which course graduates are strategically placed to influence the use of OR in their organizations. Finally, we discuss the institutional constraints encountered by graduates which limit application of course knowledge.

To determine if the course was immediately useful to participants, we interviewed students before and after the course. The survey consisted of a self-administered questionnaire that requested information on OR and reproductive health related activities including participation in OR projects and other intervention projects and teaching. Information was gathered on activities engaged in during the year prior to the course and compared to the 
behavior of the same respondents during the year following the course. The "before" questionnaire was administered on the last day of the OR course. Pre-test timing was selected to ensure that respondents understood what was meant by terms like "operations research," or "intervention studies". The post-test was administered by regular mail and by e-mail one year following the completion of the course. Survey data are available for students attending the 1999 course.

\subsection{Survey Results}

Eighteen of the 21 students in the 1999 course returned the post-course questionnaires. Ten were in research or academic positions, five were managers and three were service providers. Group involvement in research activities in general and reproductive health research in particular did not change after the CDC course. Eleven worked on research projects after the course, and twelve before. Reproductive health topics that were the subject of participant research included family planning (6 mentions); maternal/child health (6 mentions); STI/HIV ( 2 mentions), and breastfeeding, private sector involvement in RH, and female genital cutting (1 mention each).

Use of course skills The skills improvements resulting from the course most often mentioned by respondents included improved ability to define research problems, matching problems to research designs, preparing research proposals and making presentations.

The course focussed on training in intervention research, qualitative research, economic evaluation and situation analysis. These were all new topics for course participants. Respondents mentioned that two of their projects involved intervention research, four qualitative research, one economic evaluation and six situation analyses. A large portion of the research conducted was obviously applied research. Most was descriptive (e.g. economic evaluation, qualitative and situation analysis), and only two studies were described as "intervention research" - the same number of intervention studies mentioned as being conducted prior to the course.

Participants carried out other activities that made use of knowledge and materials gained in the CDC course. Four mentioned that they incorporated parts of the course in their own teaching activities. Participants from Armenia, Egypt (2 proposals), Liberia, and Zambia submitted OR proposals to the FRONTIERS small grants program and other organizations, and two reviewed OR proposals. A participant from the South African National Population Unit returned to his country and helped organize OR workshops in both 1999 and 2000, and another participant helped organize and teach an OR course in Bangladesh. The nature of their involvement with OR is perhaps best assessed in the following comments made by participants:

"I supervised four operations research projects, 'Promoting the Role of the Private Sector as RH/FP Service Providers,' 'Sustainability of Mobile Clinics in RH/FP Service Delivery,' 'Improving the utilization of post-partum care (an intervention study)', 'Impact of...RH Training on Service Providers Performance" 
"I directed a project on...effect of direct payments to personnel on [their] compliance with quality standards."

"I had a presentation on 'OR in Reproductive Health' on an interagency RH theme group organized by the UN country office. Since then, I am participating in all the meetings of the...group."

"I've organized a seminar on RH and OR for the staff of the Ministry of Statistics..."

"The operations research course ...was beneficial to me on the personal level, and help me very well in the design and carrying out of my own MD thesis."

A graduate of the 2000 course, in an unsolicited e-mail, attributed his assignment to a major family planning quality improvement study in Shandong, China to his participation in the OR course.

Graduates' potential to increase utilization of OR: Although designed for junior and midlevel researchers and managers, some graduates are already in positions where they can increase utilization of OR. One participant in the first course is the Director of an NGO. The title of a participant from the Egypt National Population Council was changed from "Programatic Research Coordinator" to "Programatic and Operations Research Coordinator" after she completed the OR course. She describes her job as "I give TA and manage researchers who carry out OR and programatic research."

Another participant stated "I joined WHO...directly after the course... I am involved in planning...implementing... and evaluating proposals, all of them include diagnostic and to a [greater] extent, intervention projects. In addition I am supervising a PhD thesis on women's development and reproductive health in Alexandria."

Constraints to Utilization of Skills Learned: Finally, the comments made by respondents also identify many constraints to activities:

"Since my arrival, I've tried to introduce the concept of OR but nobody seems to understand except the Family Planning Association... I have written a study for [them]."

"I collaborate with other organizations. Plans are always made to carry out OR to improve performance but funding is always a problem. Please send me a list of potential funding organizations."

"Right after I finished the OR course, I have been studying in the School of Public Health... to pursue my master degree majoring in Reproductive Health."

"I joined a new institute which is at the formative stage... However, I feel that in the future, I will get the opportunity to apply the knowledge... from the CDC workshop." 


\section{DISCUSSION}

The project achieved the result of institutionalizing operations research at the Cairo Demographic Center. CDC includes over 40 hours of OR instruction in its regular curricula, and is actively pursuing collaboration with $\mathrm{WHO}$ and other international donors to become a regional training site for short OR courses. This result was achieved after two years of intensive collaboration between the staffs of both CDC and FRONTIERS, and the promise of a long-term relationship between the two organizations. Elements contributing to the successful result include the background and abilities of CDC, training of CDC staff by FRONTIERS to teach OR subjects and the contribution of relevant educational materials to CDC. Most important, perhaps, was the interest of the Center's management in operations research as a way to increase the relevance of the organization to the parameter shift in reproductive health.

Upon completion of the 1999 OR course, about half of the graduates engaged in some type of operations research activity including working on OR studies, writing OR proposals, and giving seminars and lectures on OR. Some of the graduates also are on career ladders that will allow them to influence the applied research activities of large NGOs, international donors and governments.

However, our follow-up survey of 1999 course graduates also identified many constraints to the increased utilization of OR. Students did not use their OR training because they entered postgraduate degree programs or took jobs that did not provide opportunities to do OR (for example, some graduates went on to practice medicine, another graduate took a job as the head of crime statistics in Yemen). Graduates who wish to continue OR activities find there are few sources of funding for OR projects, and as junior and mid-level researchers, most still require mentoring from more experienced researchers, which, unfortunately is not available. To meet the goal of increased use of OR, we need to supplement our institutionalization activities with efforts to encourage more governments and donors to fund operations research, and begin building a program to provide mentoring to new researchers interested in OR.

\section{RECOMMENDATIONS}

To maximize capacity building, FRONTIERS project activities should become more integrated and all should embrace capacity building goals more explicitly. Specifically:

- The Small Grants Program should set aside funds to support OR projects by faculty and graduates at FRONTIERS OR training programs in Bangladesh, Costa Rica, Egypt, and Uganda.

- FRONTIERS interns should be drawn from among graduates of OR training programs.

- TA to the World Health Organization to enable them to expand OR activities should be a high FRONTIERS priority.

- FRONTIERS staff should collaborate on OR projects funded by WHO, and should also begin to work on projects with training center staff. 


\section{APPENDIX 1}

\section{List of Participants \\ Operations Research Course \\ 18 July - 17 August 1999}

\begin{tabular}{|c|c|c|c|}
\hline \# & Name & Occupation & Country \\
\hline 1 & Prof. Azizur Rahman & $\begin{array}{c}\text { Institute of Health Economics } \\
\text { University of Dhaka }\end{array}$ & Bangladesh \\
\hline 2 & Mr. Baboucarr S.M. Gaye & $\begin{array}{c}\text { Researcher } \\
\text { Pan Africa Inst. for Development }\end{array}$ & Gambia \\
\hline 3 & Ms. Bintu Adam Ibrahim & $\begin{array}{c}\text { Senior Researcher } \\
\text { National Population Council }\end{array}$ & Nigeria \\
\hline 4 & Mr. Emad Fawky Atwa & $\begin{array}{l}\text { Mansoura University } \\
\text { Fertility care Society }\end{array}$ & Egypt \\
\hline 5 & Ms. Eman Mahmoud Mostafa & $\begin{array}{c}\text { Researcher } \\
\text { CAPMAS }\end{array}$ & Egypt \\
\hline 6 & Mr. Gordon Kaluba & $\begin{array}{c}\text { Professor } \\
\text { Nakruma Teachers College }\end{array}$ & Zambia \\
\hline 7 & Mr. Jamil F.S.Al Massri & Ministry of Health & Palestine \\
\hline 8 & Ms. Karine Kuyumjyan & $\begin{array}{c}\text { Chief of Methodology and Planning State } \\
\text { Registry and Data Analysis }\end{array}$ & Armenia \\
\hline 9 & Ms. Lila Amaliah & Population Council & Indonesia \\
\hline 10 & Mr. Leon Swartz & $\begin{array}{c}\text { Assistant Director } \\
\text { National Population Unit }\end{array}$ & South Africa \\
\hline 11 & Mr. Mathew K. Flomo-Gorveaboe & $\begin{array}{c}\text { Researcher } \\
\text { Population Policy Unit } \\
\text { Ministry of Planning }\end{array}$ & Liberia \\
\hline 12 & $\begin{array}{l}\text { Mr. Mohamed Hamdy Abu El- } \\
\text { Kheir }\end{array}$ & CDC & Egypt \\
\hline 13 & Dr. Mohamed Idrees & CSI & Egypt \\
\hline 14 & Dr. Mohsen Mohamed Fathy & Ministry of Health \& Population & Egypt \\
\hline 15 & Ms. Mona Mohamed Ismail & $\begin{array}{l}\text { Researcher } \\
\text { CAPMAS }\end{array}$ & Egypt \\
\hline 16 & Dr. Nadia Abdel-Aziz Teleb Badr & $\begin{array}{l}\text { Professor of Public Health } \\
\text { Alexandria University }\end{array}$ & Egypt \\
\hline 17 & Ms. Nina Chiticaru & $\begin{array}{c}\text { Statistician } \\
\text { National Commission of Statistics }\end{array}$ & Romania \\
\hline 18 & Ms. Oulfat Naseef Harown & NPC & Egypt \\
\hline 19 & Ms. Rose Akose Malova & $\begin{array}{c}\text { Statistical Officer } \\
\text { Ministry of Planning }\end{array}$ & Kenya \\
\hline 20 & Mr. Zein El-Abedeen El-Wafai'e & CDC & Egypt \\
\hline
\end{tabular}




\section{APPENDIX I}

\section{List of Participants \\ Operation Research Course \\ 23 July - 22 August 2000}

\begin{tabular}{|c|c|c|c|}
\hline \# & Name & Occupation & Country \\
\hline 1 & Ms. Azhar Abdel Aal Mokhtar & $\begin{array}{l}\text { Demographer } \\
\text { CAPMAS }\end{array}$ & Egypt \\
\hline 2 & Ms. Fatma Mohamed El-Ashry & $\begin{array}{l}\text { Researcher } \\
\text { CAPMAS }\end{array}$ & Egypt \\
\hline 3 & Mr. Henry Kofi Alifo & $\begin{array}{l}\text { Asst. Pop. Officer } \\
\text { National Population Council }\end{array}$ & Ghana \\
\hline 4 & Mr. Hussein Mohamed Abu Taleb & $\begin{array}{l}\text { Admin. Director } \\
\text { National Population Council }\end{array}$ & Yemen \\
\hline 5 & Ms. Jasmeen Jakeya & $\begin{array}{l}\text { Raipura Thana } \\
\text { Thana Family Planning }\end{array}$ & Bangladesh \\
\hline 6 & Mr. Lamin Sabally & $\begin{array}{l}\text { Media Assistant } \\
\text { Information Services }\end{array}$ & Gambia \\
\hline 7 & Mr. Liu Baochang & $\begin{array}{l}\text { Program Officer, Shandong } \\
\text { Provincial Commission }\end{array}$ & China \\
\hline 8 & Ms. Lourdes Palomo-Nacionales & $\begin{array}{l}\text { Project Evaluation Officer } \\
\text { Commission on Population }\end{array}$ & Philippines \\
\hline 9 & Mr. Mohamed Omari & $\begin{array}{l}\text { Subject Officer, Palestinian } \\
\text { Central Bureau of Statistics }\end{array}$ & Palestine \\
\hline 10 & Ms. Nadia Abdel Rahim & $\begin{array}{l}\text { Research Assistant } \\
\text { National Population Council }\end{array}$ & Sudan \\
\hline 11 & Ms. Sati Rebecca Stephen & $\begin{array}{l}\text { Head of Department } \\
\text { Ministry of Education }\end{array}$ & Nigeria \\
\hline 12 & Mr. Tamba Fokoe & $\begin{array}{l}\text { Research Director } \\
\text { Ministry of Education }\end{array}$ & Liberia \\
\hline 13 & Mr. Zmmbodilion Yap Mosende & $\begin{array}{l}\text { Project Coordinator } \\
\text { Population Council, Manila }\end{array}$ & Philippines \\
\hline 14 & Mr. Abdelrahim S.A. Shagora & $\begin{array}{l}\text { Deputy of Palestine College of } \\
\text { Nursing }\end{array}$ & Palestine \\
\hline 15 & Mr. Okello Quinto Dickens & $\begin{array}{l}\text { Research Coordinator } \\
\text { Regional Center for Quality of } \\
\text { Health Care }\end{array}$ & Uganda \\
\hline 16 & Mr. Zia Sadique & Lecturer, University of Dhaka & Bangladesh \\
\hline 17 & Dr. Angy El Sayed Emam & Ministry of Health \& Pop. & Egypt \\
\hline 18 & Dr. Ezzat El-Shesheny & Expert, CDC & Egypt \\
\hline 19 & Mrs. Nadia Fahmy & Researcher, CDC & Egypt \\
\hline 20 & Dr. Seham M.Elsherif & CDC & Egypt \\
\hline
\end{tabular}




\section{APPENDIX II}

\section{OPERATIONS RESEARCH IN REPRODUCTIVE HEALTH COURSE AT CAIRO DEMOGRAPHIC CENTER(CDC) 18 JULY - 17 AUGUST 1999 \\ AGENDA}

\begin{tabular}{|c|c|c|c|}
\hline Date & $9.30-11.00$ & $11.30-1.00$ & $2.30-4.00$ \\
\hline $\begin{array}{l}\text { July } 18 \\
\text { Sunday }\end{array}$ & $\begin{array}{c}\text { 1.Introduction to course } \\
\text { What do RH Programs include? } \\
\text { Foreit }\end{array}$ & $\begin{array}{c}\text { 2.What is OR? } \\
\text { Foreit }\end{array}$ & $\begin{array}{c}\text { 3.Formation of Working } \\
\text { Groups(WG) } \\
\text { Making good presentations } \\
\text { Hegazi } \\
\end{array}$ \\
\hline $\begin{array}{l}\text { July } 19 \\
\text { Monday }\end{array}$ & $\begin{array}{l}\text { 4.RH Program Components } 1 \\
\text { Idris }\end{array}$ & $\begin{array}{c}\text { 5.RH Program Component II } \\
\text { Panel Discussion CSI } \\
\text { Staff* }\end{array}$ & $\begin{array}{l}\text { 6.Programmatc Constraints } \\
\text { CST/Hussein El Sayed* }\end{array}$ \\
\hline $\begin{array}{l}\text { July } 20 \\
\text { Tuesday }\end{array}$ & $\begin{array}{l}\text { 7.Discussion of Program Problems } \\
\text { in Participants own countries } \\
\text { All participants Moderation } \\
\text { Foreit } \\
\end{array}$ & $\begin{array}{l}\text { 8.Discussion of Readings } \\
\text { Assigned on } 7 / 18 \\
\text { Two discussing groups } \\
\text { Foreit / Ibrahim } \\
\end{array}$ & $\begin{array}{c}\text { 9.Identification of the Research } \\
\text { Topic } \\
\text { Foreit }\end{array}$ \\
\hline $\begin{array}{c}\text { July } 21 \\
\text { Wednesday }\end{array}$ & $\begin{array}{c}\text { 10.Working Group Meetings Four } \\
\text { Working Groups } \\
\text { Foreit/Mona }\end{array}$ & $\begin{array}{c}\text { 11.WG Research Topic } \\
\text { Presentations (Groups1\&2) } \\
\text { Hegazi/Mona }\end{array}$ & $\begin{array}{c}\text { 12.WG Research Topic } \\
\text { Presentations (Group 3\&4) } \\
\text { Hegazi/Mona }\end{array}$ \\
\hline $\begin{array}{l}\text { July } 22 \\
\text { Thrsday }\end{array}$ & $\begin{array}{l}\text { 13. Selecting An Intervention } \\
\text { Research Design } \\
\text { Foreit }\end{array}$ & $\begin{array}{c}\text { 14.Discussion of Reading on } \\
\text { Selecting a Research Design } \\
\text { (Two Groups of 10) } \\
\text { Foreit/Ibrahim }\end{array}$ & $\begin{array}{l}\text { 15.Research Proposal Contents } \\
\text { Nawar }\end{array}$ \\
\hline \multicolumn{4}{|l|}{ WEEKEND } \\
\hline $\begin{array}{l}\text { July } 25 \\
\text { Sunday }\end{array}$ & $\begin{array}{l}\text { 16.Designs for Measuring Impact } \\
\text { Foreit }\end{array}$ & $\begin{array}{l}\text { 17.Discussion of Sample } \\
\text { Research Proposals(Critic on } \\
\text { given proposals)** } \\
\text { Nawar/Ibrahim }\end{array}$ & $\begin{array}{l}\text { 18.Designs for Measuring } \\
\text { Access } \\
\text { Foreit }\end{array}$ \\
\hline $\begin{array}{l}\text { July } 26 \\
\text { Monday }\end{array}$ & $\begin{array}{c}\text { 19.Designs for Measuring Resource } \\
\text { Mobilization } \\
\text { Foreit }\end{array}$ & $\begin{array}{l}\text { 20.Discussion of Readings } \\
\text { on Experimental Designs } \\
\text { (Two Groups of 10) } \\
\text { Khan/ Foreit }\end{array}$ & $\begin{array}{c}\text { 21. Working Group Meetings } \\
\text { Presentation for Presentation of } \\
\text { Research Designs } \\
\text { Khan/ Foreit }\end{array}$ \\
\hline $\begin{array}{l}\text { July } 27 \\
\text { Tuesday }\end{array}$ & $\begin{array}{l}\text { 22. Working Group Meetings } \\
\text { Preparation for Presentation of } \\
\text { Research Designs } \\
\text { Foreit/Ibrahim }\end{array}$ & $\begin{array}{l}\text { 23.Discussion of Readings } \\
\text { on Experimental Designs } \\
\text { (Two Groups of 10) } \\
\text { Khan/ Foreit }\end{array}$ & $\begin{array}{l}\text { 24. Working Group Meetings } \\
\text { Presentation for Presentation of } \\
\text { Research Designs } \\
\text { Khan/ Foreit }\end{array}$ \\
\hline $\begin{array}{c}\text { July } 28 \\
\text { Wednesday }\end{array}$ & $\begin{array}{c}\text { 25.Working Group Meetings } \\
\text { Presentation for Presentation of } \\
\text { Research Designs } \\
\text { Khan/ Foreit }\end{array}$ & $\begin{array}{l}\text { 26.Presentation of Research } \\
\text { Designs(Group 3\&4) } \\
\text { Foreit/Ibrahim }\end{array}$ & $\begin{array}{l}\text { 26.Presentation of Research } \\
\text { Designs(Group 1\&2) } \\
\text { Foreit/Ibrahim }\end{array}$ \\
\hline $\begin{array}{l}\text { July } 29 \\
\text { Thursday }\end{array}$ & $\begin{array}{l}\text { 28.Qualitative methods I } \\
\text { Khan }\end{array}$ & $\begin{array}{c}\text { 29.Discussion of } \\
\text { Readings(Two Groups of } \\
\text { 10) } \\
\text { Khan/Kafafy } \\
\end{array}$ & $\begin{array}{l}\text { 30.Qualitative Methods II } \\
\text { Kafafy }\end{array}$ \\
\hline \multicolumn{4}{|l|}{ Weekend } \\
\hline $\begin{array}{l}\text { August } 1 \\
\text { Sunday }\end{array}$ & $\begin{array}{l}\text { Qualitative Methods III } \\
\text { Foreit }\end{array}$ & $\begin{array}{l}\text { 32.Discussion of Readings } \\
\text { (Two Groups of 10) } \\
\text { Foreit }\end{array}$ & $\begin{array}{l}\text { 33.Qualittaive Methods IV } \\
\text { Mona }\end{array}$ \\
\hline August 2 & 34.Types of Cost Analysis & 35.Planing a cost Analysis & 36.Identification \&Cost \\
\hline
\end{tabular}




\begin{tabular}{|c|c|c|c|}
\hline Monday & Homan & Homan & $\begin{array}{l}\text { Allocation } \\
\text { Homan }\end{array}$ \\
\hline $\begin{array}{l}\text { August } 3 \\
\text { Tuesday }\end{array}$ & $\begin{array}{c}\text { 37.Review of Cost Calculation and } \\
\text { Allocation Exercies } \\
\text { Homan /Foreit }\end{array}$ & $\begin{array}{l}\text { 38.Planning a Cost Analysis } \\
\text { Homan/Foreit }\end{array}$ & $\begin{array}{c}\text { 39.Identifying Measuring \& } \\
\text { Valuing Cost Components } \\
\text { Homan }\end{array}$ \\
\hline $\begin{array}{c}\text { August4 } \\
\text { Wednesday }\end{array}$ & $\begin{array}{c}\text { 40.Review of Benefit and } \\
\text { Alternative Comparison Exercise } \\
\text { Homan }\end{array}$ & $\begin{array}{l}\text { 41.Identifiyng Measuring \& } \\
\text { Valuing Program Benefits } \\
\text { Homan }\end{array}$ & $\begin{array}{c}\text { 42.Comparing Results of } \\
\text { Program Alternatives Under an } \\
\text { Economic Evaluation } \\
\text { Homan }\end{array}$ \\
\hline $\begin{array}{l}\text { August } 5 \\
\text { Thursday }\end{array}$ & $\begin{array}{c}\text { 43.Review of Benefit and } \\
\text { Alternatice Comparison Exersice } \\
\text { Homan }\end{array}$ & $\begin{array}{l}\text { 44.Dealing with Uncertainty } \\
\text { and Presenting Results of } \\
\text { Economic Evaluation } \\
\text { Homan }\end{array}$ & $\begin{array}{l}\text { 45.Roundable Discussion of } \\
\text { Economic Evaluations } \\
\text { Homan }\end{array}$ \\
\hline \multicolumn{4}{|l|}{ Weekend } \\
\hline $\begin{array}{l}\text { August } 8 \\
\text { Sunday }\end{array}$ & $\begin{array}{l}\text { 46. Situation Analysis } \\
\text { Miller }\end{array}$ & $\begin{array}{l}\text { 47.Discussion of Readings } \\
\text { (Two Groups of 10) } \\
\text { Miller/Mona }\end{array}$ & $\begin{array}{l}\text { 48. Situation Analysis } \\
\text { Miller/Mona }\end{array}$ \\
\hline $\begin{array}{l}\text { August } 9 \\
\text { Monday }\end{array}$ & $\begin{array}{c}\text { 49.Analysis of Situation Analysis } \\
\text { Data } \\
\text { Miller/Naguib }\end{array}$ & $\begin{array}{l}\text { 50.Working Group Meetings } \\
\text { Naguib/Mona }\end{array}$ & $\begin{array}{l}\text { 51. Working Group Presentation } \\
\text { of Situation Analysis Data } \\
\text { Miller/Mona }\end{array}$ \\
\hline $\begin{array}{l}\text { August } 10 \\
\text { Tuesday }\end{array}$ & $\begin{array}{l}\text { 52. Working Group Meetings } \\
\text { Naguib/Miller/Mona }\end{array}$ & $\begin{array}{c}\text { 53.Presentation of W.Group } \\
\text { on SA } \\
\text { Miller/Naguib }\end{array}$ & $\begin{array}{c}\text { 54. Working Group Presentation } \\
\text { of Situation Analysis Data } \\
\text { Miller/Mona }\end{array}$ \\
\hline $\begin{array}{l}\text { August } 11 \\
\text { Wednesday }\end{array}$ & $\begin{array}{l}\text { 55.Dissemination } \\
\text { Hegazi }\end{array}$ & $\begin{array}{l}\text { 56.Utilization of Syudy } \\
\text { Results } \\
\text { Bob Miller } \\
\end{array}$ & $\begin{array}{l}\text { 57.Working Group Meetings } \\
\text { Hegazi/Mona }\end{array}$ \\
\hline $\begin{array}{l}\text { August } 12 \\
\text { Thursday }\end{array}$ & $\begin{array}{l}\text { 58. Working Group Meetings } \\
\text { Hegazi/Mona }\end{array}$ & $\begin{array}{l}\text { 59. Working Group } \\
\text { Presentation } \\
\text { Hegazi/Mona }\end{array}$ & $\begin{array}{c}\text { 60.Working Group } \\
\text { Presentations of Dissemination } \\
\text { and Utilization Plan } \\
\text { Hegazi/Mona }\end{array}$ \\
\hline \multicolumn{4}{|l|}{ Weekend } \\
\hline $\begin{array}{l}\text { August } 15 \\
\text { Wednesday }\end{array}$ & $\begin{array}{l}\text { 61. Working Group Meetings } \\
\text { Ibrahim }\end{array}$ & $\begin{array}{l}\text { 62. Working Group Meetings } \\
\text { Ibrahim }\end{array}$ & $\begin{array}{l}\text { 63. Working Group Meetings } \\
\text { Ibrahim }\end{array}$ \\
\hline August 16 & $\begin{array}{l}\text { 64. Working Group Proposal } \\
\text { Presentation } \\
\text { Ibrahim/Al-Tawab } \\
\end{array}$ & & \\
\hline $\begin{array}{l}\text { August } 17 \\
\text { Thursday }\end{array}$ & Closing & Function & \\
\hline
\end{tabular}




\title{
APPENDIX II
}

\section{OPERATIONS RESEARCH IN REPRODUCTIVE HEALTH COURSE AT CAIRO DEMOGRAPHIC CENTER (CDC)}

\author{
COURSE 2000 \\ SUNDAY, JULY 24 - TUESDAY, AUGUST 24, 2000
}

\begin{tabular}{|c|c|c|c|}
\hline DATE & 1. $(9: 30-11: 00)$ & 2. $(11: 30-1: 00)$ & 3. $(1: 30-4: 00)$ \\
\hline Monday July 24 & Course introduction & $\mathrm{RH}$ & What is OR \\
\hline Tuesday 25 & $\mathrm{RH}$ programs & $\begin{array}{l}\text { RH program panel describes } \\
\text { program components }\end{array}$ & $\begin{array}{l}\text { RH programs II } \\
\text { Problems }\end{array}$ \\
\hline Wednesday 26 & Visit CSI & Visit CSI & $\begin{array}{c}\text { Discussion of RH program } \\
\text { readings }\end{array}$ \\
\hline Thursday 27 & $\begin{array}{c}\text { The OR proposal process and } \\
\text { contents }\end{array}$ & $\begin{array}{l}\text { Identifying the research } \\
\text { problem }\end{array}$ & Making good presentations \\
\hline Friday 28 & \multicolumn{3}{|c|}{ Weekend } \\
\hline Saturday 29 & \multicolumn{3}{|c|}{ Weekend } \\
\hline Sunday 30 & $\begin{array}{c}\text { Intervention research I: } \\
\text { experimentation and causality }\end{array}$ & $\begin{array}{l}\text { Discussion of readings on } \\
\text { research design }\end{array}$ & Experimental design II \\
\hline Monday 31 & Analysis of experiments & Design and analysis exercises & $\begin{array}{c}\text { Design and analysis } \\
\text { exercises }\end{array}$ \\
\hline Tuesday 1 Aug. & $\begin{array}{l}\text { Critique of research studies } \\
\text { (discussion of readings) }\end{array}$ & $\begin{array}{c}\text { Critique of sample research } \\
\text { proposals }\end{array}$ & $\begin{array}{l}\text { Formation of working } \\
\text { groups/ First working group } \\
\text { meeting for identification of } \\
\text { OR problem }\end{array}$ \\
\hline Wednesday 2 & $\begin{array}{l}\text { Working group meeting II } \\
\text { (research design selection) }\end{array}$ & $\begin{array}{c}\text { Working group meeting III } \\
\text { (problem and design) }\end{array}$ & $\begin{array}{c}\text { Working group meeting IV } \\
\text { (problem and design) } \\
\end{array}$ \\
\hline Thursday 3 & Working group presentations & Working group presentations & $\begin{array}{l}\text { Introduction to qualitative } \\
\text { research } \\
\end{array}$ \\
\hline Friday 4 & \multicolumn{3}{|c|}{ Weekend } \\
\hline Saturday 5 & \multicolumn{3}{|c|}{ Weekend } \\
\hline Sunday 6 & Qualitative research II & $\begin{array}{c}\text { Discussion of readings on } \\
\text { qualitative research }\end{array}$ & Qualitative research III \\
\hline Monday 7 & $\begin{array}{l}\text { Working group meeting } \\
\text { (qualitative component) }\end{array}$ & $\begin{array}{l}\text { Working group meeting } \\
\text { (qualitative component) } \\
\end{array}$ & $\begin{array}{l}\text { Working group meeting } \\
\text { (qualitative component) } \\
\end{array}$ \\
\hline Tuesday 8 & $\begin{array}{c}\text { Working group presentation of } \\
\text { qualitative component }\end{array}$ & $\begin{array}{l}\text { Working group presentation } \\
\text { of qualitative component }\end{array}$ & $\begin{array}{c}\text { Introduction to economic } \\
\text { analysis } \\
\end{array}$ \\
\hline Wednesday 9 & Economic analysis II & $\begin{array}{c}\text { Discussion of readings on } \\
\text { economic anlaysis }\end{array}$ & $\begin{array}{c}\text { Economic analysis exercise } \\
\text { I }\end{array}$ \\
\hline Thursday 10 & Economic analysis exercise II & $\begin{array}{l}\text { Working group meeting } \\
\text { (economic eval. component) }\end{array}$ & $\begin{array}{l}\text { Working group meeting } \\
\text { (economic eval component) }\end{array}$ \\
\hline
\end{tabular}




\begin{tabular}{|c|c|}
\hline Friday 11 & Weekend \\
\hline Saturday 12 & Weekend \\
\hline
\end{tabular}

\begin{tabular}{|c|c|c|c|}
\hline DATE & 1. $(9: 30-11: 00)$ & 2. $(11: 30-1: 00)$ & 3. $(1: 30-4: 00)$ \\
\hline Sunday 13 & $\begin{array}{l}\text { Working group presentation of } \\
\text { economic component }\end{array}$ & $\begin{array}{l}\text { Working group presentation } \\
\text { of economic component }\end{array}$ & $\begin{array}{l}\text { Dissemination of study } \\
\text { results }\end{array}$ \\
\hline Monday 14 & Utilization of study reseults & $\begin{array}{c}\text { Working group meeting } \\
\text { (dissemination and utilization } \\
\text { plan) }\end{array}$ & $\begin{array}{c}\text { Working group meeting } \\
\text { (dissemination and } \\
\text { utilization plan) }\end{array}$ \\
\hline Tuesday 15 & Situation analysis I & $\begin{array}{l}\text { Discussion of situation } \\
\text { analysis readings }\end{array}$ & Situation analysis II \\
\hline Wednesday 16 & $\begin{array}{l}\text { Analysis of situation analysis data } \\
\text { I }\end{array}$ & Descriptive statistics for SA & $\begin{array}{c}\text { Presentation of situation } \\
\text { analysis data }\end{array}$ \\
\hline Thursday 17 & Working group meetings & Working group meetings & Working group meetings \\
\hline Friday 18 & \multicolumn{3}{|c|}{ Weekend } \\
\hline Saturday 19 & \multicolumn{3}{|c|}{ Weekend } \\
\hline Sunday 20 & $\begin{array}{l}\text { Working group presentation of } \\
\text { SA }\end{array}$ & $\begin{array}{c}\text { Working group presentation } \\
\text { of SA }\end{array}$ & $\begin{array}{c}\text { Working group meetings } \\
\text { for final proposal }\end{array}$ \\
\hline Monday 21 & $\begin{array}{c}\text { Working group meeting for final } \\
\text { proposal }\end{array}$ & $\begin{array}{l}\text { Working group meeting for } \\
\text { final proposal }\end{array}$ & $\begin{array}{c}\text { Working group meetings } \\
\text { for final proposal }\end{array}$ \\
\hline Tuesday 22 & $\begin{array}{c}\text { Hand in proposals to reviewers } \\
\text { Time for presentation preparation } \\
\text { and practice }\end{array}$ & $\begin{array}{l}\text { Time for presentation } \\
\text { preparation and practice }\end{array}$ & $\begin{array}{l}\text { Working group } 1 \\
\text { presentation }\end{array}$ \\
\hline Wednesday 23 & Working group 2 presentation & Working group 3 presentation & $\begin{array}{c}\text { Working group } 4 \\
\text { presentation }\end{array}$ \\
\hline Thursday 24 & Course evaluation & \multicolumn{2}{|c|}{ Closing ceremonies } \\
\hline
\end{tabular}

